
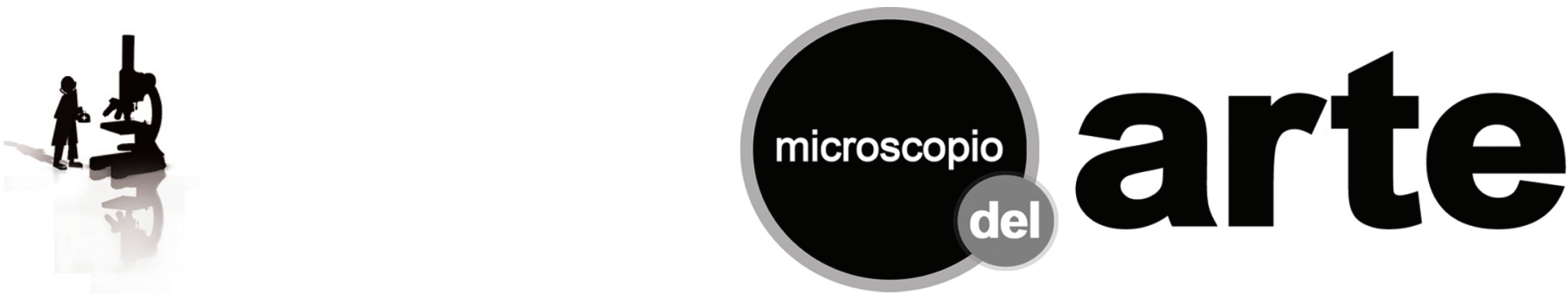

\title{
LA TRAVIATA
}

\section{La camelia de Verdi}

\begin{abstract}
Adaptada de la novela La Dama de las Camelias de Alejandro Dumas hijo, "La Traviata", versión musicoteatral de Guiseppe Verdi, constituye un hito en la historia de la ópera que reúne las profundas contradicciones de la sociedad del siglo XIX, con las implicancias de la enfermedad que atravesaba la época: la tuberculosis.
\end{abstract}

Periodista: Francisca Araya F./Asesor: Ernesto Payá G.

Violetta Valéry es la versión italiana y operística de Marguerite Gautier de La dama de las camelias; una joven cortesana mantenida por distinguidos señores, quien se mueve entre el lujo, las fiestas parisinas y la enfermedad que padece: la tuberculosis.

En la adaptación de Francisco María Piave, el drama gira en torno al amor que surge entre Violetta y Alfredo Germont, un hombre de clase alta que pone en riesgo la reputación de su familia al involucrarse con esta mujer de vida fácil; tanto, que el padre de Alfredo intenta persuadir a la joven Violetta para que lo abandone, tras lo que, y según las creencias de la época, su enfermedad se agravaría.

Se dice que Alejandro Dumas conoció a la verdadera protagonista de esta historia; Alphonsine Pléssis y que fueron amantes hasta su muerte. Ella habría inspirado el personaje; el mismo que se convirtiera en todo un símbolo del Romanticismo gracias a su excelente representación de la sociedad francesa de la época y de otros países europeos; ese abismo entre estrictos códigos morales burgueses, donde la prostitución era tan condenada como permitida.

Al mismo tiempo, en el siglo XIX, se tenía la creencia de que la tuberculosis podía ser causada por preocupaciones mentales o pérdidas afectivas, por lo que quienes la padecían, se convertían en una suerte de heroínas sentimentales, como Violette.
Sin embargo, tal como afirma Walter Ledermann en su libro "Una historia personal de las bacterias", Gaspard Laurent Bayle es a quien "debemos el concepto moderno de tuberculosis como un proceso mórbido progresivo, expresado en su obra $<<$ Recherches sur la ptisis poumonaire $>>$ (Paris, 1810)...Si bien la estimó específica y degenerativa, erró al suponerla hereditaria y no contagiosa, pero supo deducir de la aparición de tubérculos en órganos alejados del pulmón, su carácter de mal generalizado: discrasia o diátesis". ${ }^{1}$ Así, poco a poco, se logró desmitificar la idea, arraigada desde los tiempos Hipócrates, de que la tuberculosis afectaba personas "de contextura fina y tierna, con vocecita aguada, piel delgada y clara, cuello largo, pecho angosto y omóplatos que sobresalen".2

El estreno de La Traviata se llevó a cabo el 6 de marzo de 1853, en el Teatro La Fenice de Venecia y fue un rotundo fracaso. Muchos lo atribuyen a una mala representación del elenco, pero al parecer, el factor más influyente fue que La Traviata era la primera ópera dramática que situaba su acción en un tiempo contemporáneo al que fue escrita. Es por eso que un año después, Verdi ofreció una nueva representación, esta vez, ambientada en el siglo XVII, donde en medio del debate generado por la "inmoralidad" de la obra, La Traviata se convirtió en la más popular de las creaciones de Giuseppe Verdi.

1. Ledermann, W. Una historia personal de las bacterias. Ril Editores, Santiago de Chile, 2007; p.161

2. Castiglioni A. History of tuberculosis. Medical Press, New Cork, 1933. Ledermann, W. lbid.
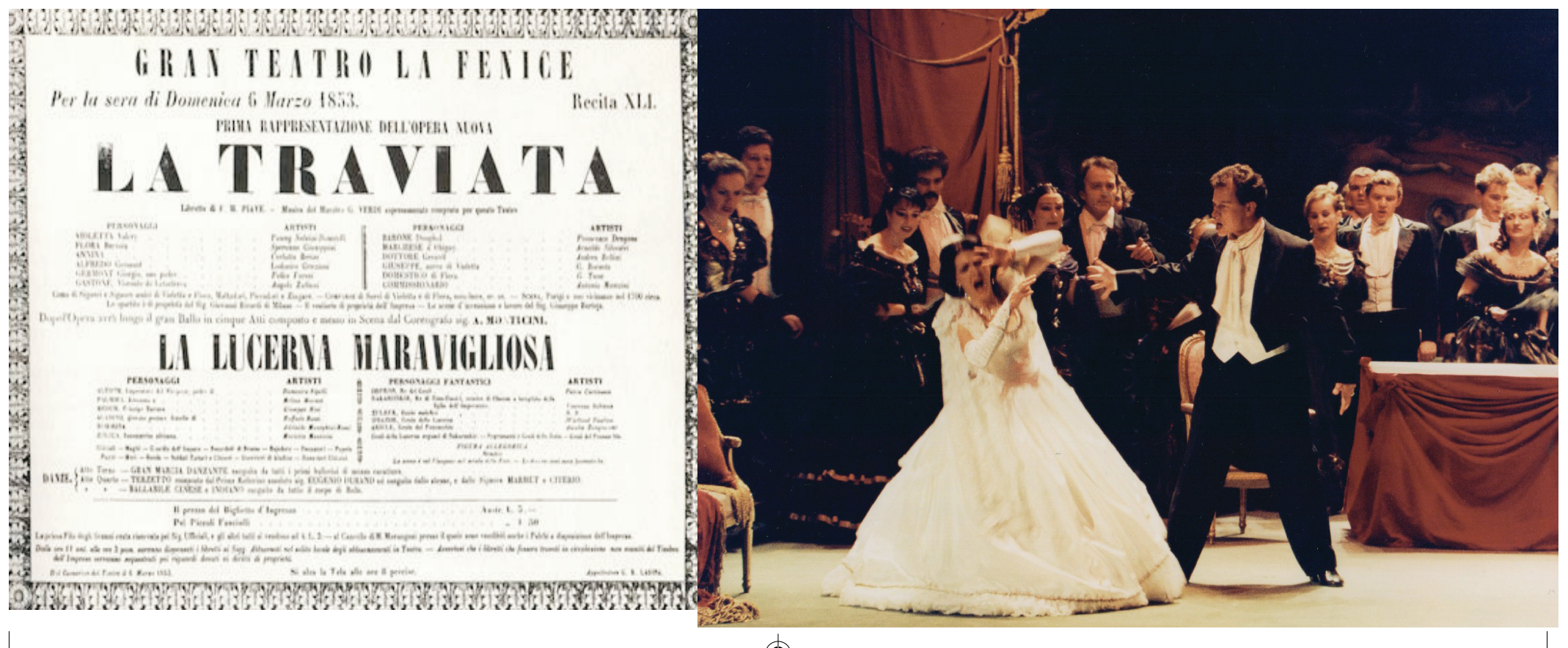

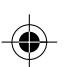

